UNIO - EU Law Journal. Vol. 4, No. 1, January 2018, pp 117-132.

®2018 Centre of Studies in European Union Law

School of Law - University of Minho

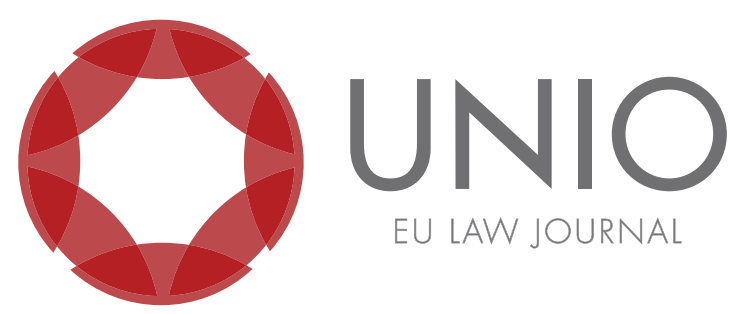

\title{
The Portuguese judicial control in merger cases
}

\section{Marta Campos*}

ABSTRACT: This text will analyze the type of judicial control carried out by the Competition, Regulation and Supervision Court in actions to challenge decisions made by the Competition Authority in merger control procedures, specifically the decision concerning the formal notice that the merger is not subject to the control procedure and decisions of merit of opposition and nonopposition simple or with commitments.

KEYWORDS: concentration of companies - type of judicial control - binding - discretion.

\footnotetext{
* Judge in the Competition, Regulatory and Supervisory Court of Portugal.
} 


\section{Introduction}

The decisions taken by the Portuguese National Competition Authority (NCA) in "merger control procedure" may be contested before the Competition, Regulation and Supervision Court (CRSC), as stipulated in Article 92 (1) of the Portuguese Competition Law (PCL). ${ }^{2}$

The fact that the first-line decision-maker is an administrative authority raises questions about potential problematic issues with the type of judicial control exercised. ${ }^{3}$ The problem is the existence and/or degree of judicial deference to the administrative decision, considering fundamental and conflicting values, such as the principle of Separation and interdependence of powers, on the one hand, and the right to effective judicial protection, on the other, all being normative commands of the founding idea of the rule of law.

This is the legal problem that we will develop in this text, which will be circumscribed, by its importance, to four typical NCA decisions taken under that procedure, namely: the formal decision that the merger is not covered by the merger control procedure [see Article 50 (1) (a) of the PCL]; and decisions on the merits, specifically the prohibition decision [see Article 53 (1) (b) of the PCL], the simple non-opposition decision [see Article 50 (1) (b) and 53 (1) (a), both of the PCL] and non-opposition decision accompanied by the imposition of conditions or obligations aimed at ensuring compliance with undertakings given by the notifier [see Article 50(2) and 53 (3), both of the PCL].

At the end, it may be noted that, although this is a problem whose response must at least be reconciled with domestic law, there is, with some exceptions, a significant convergence between the solutions reached at this level and the solutions which are assumed by European Union law. That is because as regards merger control, and contrary to what is done in the field of sanctions, the matrix of the two legal systems is the same. Both are in the "province of Administrative law". ${ }^{4}$

\section{Applicable rules}

In European Law, although Articles 101 and 102 of the TFEU, which once served to regulate this matter, remain in full force, the merger control is, currently, regulated by the Regulation (EC) N. ${ }^{\circ} 139 / 2004$ of 20 January 2004 and the Regulation (EC) N. ${ }^{\circ} 802 / 2004$ of the Commission of 7 April 2004, which are applicable to mergers classified as having a 'Community dimension'. ${ }^{5}$ This means that European Competition law is not directly applicable to the control procedures of mergers of undertakings within the jurisdiction of the NCA, which are subject to the PCL. ${ }^{6}$

To fill this gap, Nicolas Petit and Rabeux Louise ${ }^{7}$ suggest the principle of

\footnotetext{
${ }^{1}$ See section of Section II, Chapter III, of the PCL.

${ }^{2}$ Law no. 19/2012, of 08.05.

${ }^{3}$ See Jan S. Oster, "The Scope of Judicial Review in the German and U.S. Administrative Legal System", German Law Journal, vol. 9, n. 10 (2008): 1267.

${ }^{4}$ Pedro Costa Gonçalves, Controlo de Concentrações no Direito Português (uma Visão JusAdministrativa)", Revista de Concorrência e Regulação, Ano II, n. o 7/8 (2011): 246.

${ }^{5}$ See Article 1 (1) of Regulation No 139/2004.

${ }^{6}$ Cf. in this sense, Margarida Rosário da Fonseca and Luís do Nascimento Ferreira, O Procedimento de Controlo das Operações de Concentração de Empresas em Portugal (Coimbra: Almedina, 2009), 192. Although the authors' claims are based on the previous Law on Competition, they remain current.

${ }^{7}$ Nicolas Petit and Rabeux Louise, "Judicial Review in French Competition Law and Economic
} 
procedural autonomy should serve that function. So the solution must be found in the domestic legal order. ${ }^{8}$

However, this is not a unanimous position. There are some authors that propose a solution within the parameters defined by European Competition law. This is the case of Margarida Rosário da Fonseca and Luís do Nascimento Ferreira, based on the idea of approximation and with support, among other things, on the following grounds: in the general principle of interpretation in accordance with European Union law and; the principle of effective judicial protection enshrined in Article 268(4) of the Portuguese Constitution. ${ }^{9}$ These authors propose parameters inspired by European case-law, specifically the decision of the Court of First Instance (CFI) in the Tetra Laval II case, ${ }^{10}$ and the decisions of the CFI and, on appeal, of the Court of Justice of the European Union (CJEU) in Impala/SonyBMG. ${ }^{1112}$

Notwithstanding the fact that the jurisprudence of the European Union Courts is relevant as a criterion for interpretation, we do not fully subscribe to the aforementioned statement as it begins, develops, and ends in the case-law of the European Union.

Not only is that case-law not entirely law-creating, since it forms part of a legal framework constituted by the rules on judicial control embodied in the TFEU which apply only to the Court of Justice of the European Union (CJEU), EU law on merger control is not, as previously stated, directly applicable. Consequently, the answer must start and be reconciled with the national regulatory parameters, that is to say, it is, at least in the first place, a domestic law problem.

Saying that, judicial control must respect Articles 3(1), 71(2) and 91(5) of the Code of Procedure in the Administrative Courts (CPAC), which are applied through Articles 91 and 92 (1), both of the PCL.

\section{Discretionary and binding - criterion of distinction}

According to rules mentioned above, judicial control, related to the discretionary activity of the administration is more limited.

By virtue of the evolution of the principle of legality, it is now certain that administrative activity is never entirely discretionary, since it is bound by, at least, competence and purpose. Consequently, what matters, for the purposes of applying the CPAC rules referred to earlier, is not to identify discretionary acts and/or linked acts but discretionary and/or linked decision-making segments. However, what precisely these segments of discretion consist of is quite controversial.

\footnotetext{
Regulation", in Judicial Review in French Competition Law and Economic Regulation: A Post Commission v. Tetra Laval Assessment' (Gronigen: Europe Law Publishing, 2009): 117, available online at http:/ / orbi. ulg.ac.be/bitstream/2268/41214/1/National $\% 20$ courts $\% 20$ and $\% 20$ the $\% 20$ standard $\% 20$ of $\% 20$ review $\% 20$ in $\% 20$ competition $\% 20$ law $\% 20$ and $\% 20$ economic $\%$ 20regulation.pdf.

${ }^{8}$ In accordance with that principle, in the absence of Union rules on the subject, it is for the domestic legal system of each Member State to lay down those rules, provided, however, that they are no less favorable than those governing similar situations governed by domestic law (principle of equivalence) and which make it practically or excessively difficult to exercise the rights conferred by Union law (principle of effectiveness) - cf. to that effect VEBIC, C-439/08, EU: C: 2010: 739, paragraph 63 and Nike European Operations Netherlands, C-310/14, EU: C: 2015: 690, paragraph 28 and case-law referred to therein).

${ }^{9}$ Margarida Rosário da Fonseca and Luís do Nascimento Ferreira, O Procedimento..., 191-193.

${ }^{10}$ Judgement Tetra Laval II , Case C-12/03 P.

${ }^{11}$ Judgements Impala / SonyBMG, Cases T-464/04 and C-413/06 P.

${ }^{12}$ See Margarida Rosário da Fonseca and Luís do Nascimento Ferreira, O Procedimento..., 193-198.
} 
The divergences develop mainly around two main axes (i) on the one hand, the distinction between volitional discretion and cognitive discretion; (ii) and, on the other hand, the choice between a conceptual or methodological criterion and a dogmatic criterion. They are not two watertight axes, but they intersect, as will be explained.

The first, which corresponds essentially to the classical approach, is based on the formal differentiation between the determination and the prediction of the norm. The discretion in the determination of the norm corresponds, in German doctrine, to the discretion itself (or discretionary in determining or volitional) and the discretion in the prediction of the norm corresponds to a margin of appreciation (or discretion in the bypothesis or cognitive). ${ }^{13}$

In general terms, discretion in the statute focuses on the legal consequences of the rule, and can take two forms: the discretion of action; and the discretion of choice. The former is the option of acting or not acting and is often affirmed; "through the permissive deontic concept ('may')". ${ }^{14}$ The latter presupposes, in turn, the choice between two or more actions allowed by the norm, whether they are provided as alternatives, or the standard is limited to defining an objective and to indicate a core of decision criteria. ${ }^{15}$

According to Vieira de Andrade, the doctrine never had doubts as to the existence of discretion in these cases. The divergences arise mainly in discretion in the bypothesis or cognitive, that is to say, when the law uses indeterminate concepts in the normative prediction. ${ }^{16}$

Thus, at one extreme, there are positions that exclude the indeterminate concepts of discretionary activity, since they constitute a logical-subsonic activity of application of the law and, to that extent, are strictly linked. ${ }^{17}$ This is the case in German case-law, whose rule is to admit administrative discretion only when it is expressly recognized by law, by using terms such as "may" or "similar", and that makes the distinction between prediction (Tatbestand), subsumption (Subsumtion) and determination (Rechtsfolge) to limit discretion to this third element, thus corresponding to the recognition of volitional discretion. ${ }^{18}$ Although exceptions are allowed, such as "procedural impracticability to carry out, in the course of judicial proceedings, a contentious examination of the sub-judicial judgment by the administrative authority", ${ }^{19}$ it is submitted that the courts in Germany exercise a high level of judicial control which, according to Michael Harker, Sebastian Peyer and Katryn Wright, is particularly true in merger cases. ${ }^{20}$

\footnotetext{
${ }^{13}$ See António Cadilha, "Os poderes de pronúncia jurisdicionais na acção de condenação à prática de acto Devido e os limites funcionais da justiça administrativa”, Estudos em Homenagem ao Prof. Doutor Sérvulo Correia, vol. II, Faculdade de Direito da Universidade de Lisboa (Coimbra: Coimbra Editora, 2010):. 174. See also Ana Raquel Gonçalves Moniz, "A discricionariedade administrativa: reflexões a partir da pluridimensionalidade da função administrativa”, O Direito, 144, III, (2012), 614 and Jan S. Oster, The Scope..., 1268-1271.

${ }^{14}$ José Carlos Vieira de Andrade, “ Os poderes de cognição e de decisão do juiz no quadro do actual processo administrativo de plena jurisdição”, Cadernos de Justiça Administrativa, n. 101 (2013), 55.

${ }^{15}$ See António Cadilha, Os poderes...,175; Jan S. Oster, The Scope..., 1270.

${ }^{16}$ See António Cadilha, Os poderes..., 175-176; Jan S. Oster, The Scope..., 1269.

${ }^{17}$ See António Cadilha, Os poderes...,185-186, supra note 44.

${ }^{18}$ See António Cadilha, Os poderes..., 182-185; Jan S. Oster, The Scope..., 1269; Yutaka Arai-Takahashi, "Discretion in German Administrative Law: Doctrinal Discourse Revisited", European Public Law, vol. 6, 1 (2000): 70 and 73-75.

${ }^{19}$ See António Cadilha, Os Poderes..., 184. According to the same author, one of the exceptions allowed by German case-law is whether the decision involves prospective judgments or risk assessment, in particular in the context of administrative economic law or the environment.

${ }^{20}$ Michael Harker, Sebastian Peyer and Katryn Wright, "Judicial scrutiny of merger decisions in the EU, UK and Germany”, International and Comparative Law Quarterly”, vol. 60, (2011): 94. Yutaka Arai-
} 
Moreover, , there are understandings that postulate the existence of a margin of appreciation in relation to indeterminate concepts, although not in completely convergent terms, being mainly in this area that the distinction between the conceptual or methodological criterion and the dogmatic criterion appeared.

Thus, certain theses - those adopting a conceptual or methodological criterion - are based on the "meaningful-conceptual content" of norms, as if discretion were based on the "nature of things". ${ }^{21}$ Starting from this approach, there are, as described by Castanheira Neves, two broad guidelines: one that admits the possibility of a discretionary decision in relation to all indeterminate concepts; and the one that accepts it only in relation to the so-called concepts of value. ${ }^{22}$

Next to the more restrictive theses, we can situate the concept of technical discretion developed by Italian doctrine. ${ }^{23}$ It is also a cognitive discretion and includes only; "cases in which administrative activity is developed according to technical criteria and not in the light of any indeterminate concepts or on the basis of criteria of common experience" 24 and, within technical judgments, does not cover the so-called judgments of existence, but only the judgments of probability, that is, the judgments "on the orientation of a particular causal nexus involving a prognosis", ${ }^{25}$ which have a "markedly opinionated and evaluative character" ${ }^{26}$

For the dogmatic criterion, what matters is the existence of a "deliberate legislative intention", ${ }^{27}$ to be recognized by interpretation, which, implicitly or explicitly, attributes discretion to the Administration.

This criterion includes the so-called authorization theory supported by some German doctrine. ${ }^{28}$ Also included in this line is the Chevron doctrine adopted in the USA, which was created by a Supreme Court decision in Chevron U.S.A. Inc. v. Natural Resources Defense Council, Inc., 15.06.1984. The original thesis adopted by the Supreme Court consists of two steps ("Chevron step-one" and "Chevron step-two") and a third one ("Chevron step-zero") was added following doctrinal elaboration and Supreme Court decisions. The first step determines whether Congress has regulated the matter in a precise, clear or unambiguous way, i.e., whether the rule is not indeterminate. In this hypothesis, there is no judicial deference by the court. It is further argued that this judgment must be carried out in accordance with the traditional tools of interpretation of the law. ${ }^{29}$

It is important to note that the conceptual and dogmatic criteria can work together with the differentiation between cognitive discretion and volitional discretion, being criteria for measuring the margin of decision in the field of indeterminate concepts, as can be applied autonomously within a unitary theory of administrative discretion. ${ }^{30}$

Takahashi advances with historical reasons to explain this intensity of judicial oversight.

${ }^{21}$ Castanheira Neves, "O problema da discricionariedade", Digesta, vol. 1 (Coimbra: s/e, 1995): 578.

${ }^{22}$ Castanheira Neves, O problema..., 580-581.

${ }^{23}$ Our administrative case-law has accepted this concept of technical discretion - cf., for example, the Supreme Administrative Court judgment of 27.10.2016, case $\mathrm{n}^{\circ}$. 01071/11, and the Supreme Administrative Court judgment of 12.05.2016, proc. 0236/16.

${ }^{24}$ Miguel Nogueira de Brito, "Sobre a discricionariedade técnica", Revista de Direito e de Estudos Sociais, 36 (1994): 38-39.

${ }^{25}$ Miguel Nogueira de Brito, Sobre a discricionariedade..., 41.

${ }^{26}$ Miguel Nogueira de Brito, Sobre a discricionariedade..., 41.

${ }^{27}$ Castanheira Neves, O problema..., 577.

${ }^{28}$ See António Cadilha, Os poderes..., 178; Jan S. Oster, The Scope..., 1273-1275; Yutaka Arai-Takahashi, Special..., 75 .

${ }^{29}$ See Jan S. Oster, The Scope..., 1280-1284.

${ }^{30}$ See António Cadilha, Os poderes..., 181-182. 
For this unitary theory, discretion encompasses both indetermination in terms of legal consequences, and indeterminacy at the level of prediction, through the use of indeterminate concepts. ${ }^{31}$ It is argued that this distinction is artificial, only being practicable on a strictly logical-formal plane, ${ }^{32}$ since "there is a bond or discretion ... it will have one and the other to refer to the application of the norm as a whole, in its unitary correlation between the bypothesis and statuition, without being able to say that one or the other is located exclusively in the application of any of these abstract (non-autonomous) elements of the norm". ${ }^{33}$

EU case-law also makes no distinction between prediction and statute, regardless of discretion. As a safe criterion of distinction, there is no more than an affirmation of the existence of a discretion in relation to complex economic assessments, which is reflected in the recognition that the Commission; "has a certain discretionary power, in particular as regards economic assessments and a margin of discretion underlying the rules of an economic nature which form part of the Merger Regulation"- see inter alia the CJEU judgment in Case C-68/94 Kali and Sal\%, paragraph 223, judgment of the CJEU in Tetra Laval (Case C-12/03 P), paragraphs 38 and 39 and judgment of the CFI in Case Airtours (Case T-342/99), paragraph 64.

Among us, the CRSC has already appraised and decided some actions to challenge final decisions rendered by the NCA in merger cases. The most important is the judgment rendered in case $n^{\circ} .3 / 13.5 Y Q S T R$, which recognized discretion even when indeterminate concepts are involved and also recognized that the substantive decisionmaking power of the NCA is included in its margin of free decision because it involves prognosis judgments.

\section{What is the best criterion?}

In first place, we think that approaches that are based on conceptual or methodological criteria should be rejected, since, in the strict sense of legal science, one can conclude with Castanheira Neves that the discretionary; "does not impose itself as an autonomous methodological category within the general methodological framework of the application of law or "law enforcement". ${ }^{34}$

More importantly, however, such approaches are not considered to take into account the principles underlying the recognition of administrative discretion, in particular, the principle of Separation and interdependence of Powers and the principle of Legality. What results from these principles is that discretion is a creation of the legislator. That is to say, in simplified terms, there is only discretion when the legislator wants and can, so that, in areas where the legislator can attribute discretion to the Administration, the determination of this own space of valuation has to go through the measurement of his will, to be interpreted in terms similar to those that are part of the theory of normative habilitation and the "Chevron doctrine". Therefore, legal science arises here through the application of the criteria of interpretation of the law and not through conceptualizations around the structure of standards.

In the end, it is possible to reach understandings that are totally or partially convergent with these approaches. However, the course is not the same, that is, it will not be based on aprioristic conceptions centered on the structure of norms, closed

\footnotetext{
31 Ana Raquel Moniz, A Discricionariedade..., 644-645. António Cadilha also maintains a broad concept of discretion.

32 Ana Raquel Gonçalves Moniz, A discricionariedade..., 614.

${ }^{33}$ Castanheira Neves, O problema..., 586.

${ }^{34}$ Castanheira Neves, O problema..., 595.
} 
in an abstractionism oblivious of the fundamental principles underlying the problem. These elements, at most, may be relevant, as interpretative criteria, to conclude that this was the will of the legislator.

In part for the same reasons, we also reject approaches that are based on a differentiation between prediction and statuition of the norm, because, in general, they also rely on conceptual or methodological foundations, by referring undetermined concepts to a task of logical-subscriptive application of the law based on parameters related to the structure of the standards.

Moreover, even when - as appears to be the case in German case law - they converge the differentiation between prediction, subsumption and statuation with an express intention of the legislator in relation to the last element, translated into the use of permissive terms such as "may", they start from a conception of discretion that equates it with a certain notion of free choice between equivalent solutions. This idea is also found in the case law of the Supreme Administrative Court, through the definition of discretion as a "freedom of choice between several solutions considered as equally possible [the Administration freely chooses one of the solutions indicated in the law..."] good, any of them . $^{35}$

This conception is to reject. First, because discretion is not, according to Ana Raquel Moniz, an act of will, but an "act of judgment", ${ }^{36}$ that is, it is not an act of subjective will, which carries with it a certain idea of arbitrariness, but a rational decision. ${ }^{37}$ Second, the essential nucleus of the concept of discretion is not the idea of choosing between two or more possible and equivalent solutions, which may lead to the misconception of excluding the indeterminate concepts used in the prediction of the law. The essential nucleus of the concept lies in the pursuit of the public interest in the concrete case, subordinated to the duty to adopt the best solution for that interest. ${ }^{38}$

The pursuit of the public interest in the concrete case may depend not only on the legal consequences and the decision on whether, in light of the best solution to the pursuit of the public interest, it is necessary for the Administration to act or not to act or for the measure to be adopted from several possible solutions. The pursuit of the public interest in the concrete case may also depend on the weights and evaluations that must be undertaken to assess the operating assumptions and the measures to be applied. Consequently, there are no a priori reasons to exclude from discretion the indeterminate concepts used by the legislator in defining the provision of the standard.

Having clarified these points, it is considered that what matters is, through interpretation of the law, to determine whether there is a "delegation made by the legislator to the agent to find the solution in the particular case". ${ }^{39}$ Or, in other words, it is necessary to conclude that the matter makes part of the essential nucleus of the administrative activity, which is immune to interference from other powers, under penalty of decharacterising and emptying the functional specialization of each one. ${ }^{40}$ This is, in essentially terms, the meaning of the principle of Separation and interdependence of powers. What, it should be noted, it does not mean is an immense or completely open field of possibilities, since this criterion has to be reconciled with the material grounds of administrative discretion, which are (i) the fact that the administration is better placed

\footnotetext{
${ }^{35}$ Decision of 03.03.2016, case n. ${ }^{\circ} 0768 / 15$.

${ }^{36}$ Ana Raquel Gonçalves Moniz, A discricionariedade..., 604.

${ }^{37}$ Ana Raquel Gonçalves Moniz, A discricionariedade..., 605.

${ }^{38}$ See Ana Raquel Gonçalves Moniz, A discricionariedade..., 608-609.

39 António Augusto Costa, "A erosão do princípio da legalidade e a discricionariedade administrativa", Cedipre Online, 12 (2012): 9, available at http://www.fd.uc.pt/cedipre/publicacoes/online/public_12.pdf.

${ }^{40}$ António Cadilha, Os poderes, 165.
} 
(in terms of expertise) to pursue the public interest in the case and; (ii) the democratic legitimacy of the Administration.

In this context, what should be noted is that the NCA is an independent administrative entity and where the exercise of discretionary activity by independent administrative entities is concerned, which may be designated as regulatory discretion, ${ }^{41}$ the material ground for discretion cannot be found in a strong democratic legitimacy and political responsibility.

Consequently, the conciliation of the dogmatic criterion with the material grounds of discretion leads to the circumscription of the said interpretative task to the decisionmaking segments in relation to which it must be recognized that the administrative decision-maker is the best positioned entity to determine the best solution for the public interest to be realized. This means that regulatory discretion can be recognized only in the decision-making segments that involve: technical judgments; prognosis judgments; resource rationing judgments; or strategic decisions. ${ }^{42}$

On the other hand, in the case of those segments and, essentially, for the same reasons, the interpretative effort must be taken in the negative, i.e., in the absence of reasons to the contrary, it must be concluded that the legislature wanted to assign to the administrative entity an own space valuation. And with this understanding, it is believed that the right to effective judicial protection is safeguarded, since the recognition of regulatory discretion is not arbitrary, but is based on the principle of Separation of interdependence of powers, associated with a material or substantive foundation.

It is important to note that these considerations do not differ essentially from those under European Competition law with regard to merger control.

Thus, in the first place, the starting point is also a legal rule, in particular, Article 263 TFEU.

Secondly, to justify to the limited judicial control resulting from that provision is also institutional, as reflected in the principle of Separation of powers. ${ }^{43}$ In addition, there is a material basis, which is the Commission's greater technical preparation vis-a-vis the courts. ${ }^{44}$

Thirdly, it is recognized that the subject has fundamental rights, such as the right to a fair trial enshrined in Article 6 (1) of the European Convention on Human Rights. ${ }^{45}$ Finally, there is discretion when complex economic assessments are involved. ${ }^{46}$

\section{Binding and discretionary segments in the NCA's decisions}

Once the criterion has been identified, it should be applied to the decisions of the NCA in the merger control procedure identified in the introduction.

Thus, in the first place, there is no discretion, but binding, concerning jurisdiction, which, according to Article 19 (1) (d) of the respective Statutes, belong to the Board of Directors. This is a direct result of the principle of Legality.

\footnotetext{
${ }^{41}$ See about this concept and characterization, Ana Raquel Gonçalves Moniz, A discricionariedade..., 641 644.

${ }^{42}$ Ana Raquel Gonçalves Moniz, A discricionariedade..., 642.

${ }^{43}$ Michael Harker, Sebastian Peyer and Katryn Wright, Judicial scrutiny of merger..., 116; José Carlos Laguna de Paz, "Understanding the limits of judicial review in European competition law", Jornal of Antitrust Enforcement, vol. 2, n. ${ }^{\circ} 1$ (2014): 204.

${ }^{44}$ Michael Harker, Sebastian Peyer and Katryn Wright, Judicial scrutiny of merger..., 116.

${ }^{45}$ José Carlos Laguna de Paz, Understanding the limits..., 204.

${ }^{46}$ See José Carlos Laguna de Paz, Understanding the limits..., 215-218.
} 
Secondly and on the same basis, there is no discretion but binding, as regards the typical protected public interest, which is the promotion and defense of competition, in the specific terms set out in Article 41(1) of the PCL, translated into the; need to preserve and develop, in the interests of intermediate and final consumers, effective competition in the national market or in a substantial part thereof. This means, for example, that the NCA cannot authorize a concentration in accordance with the criterion set out in Article 41(1) of its Statutes, that is to say "when the benefits accruing therefrom for the pursuit of strategic interests of the national economy to overcome, in particular, the inherent disadvantages of competition". This is a decision reserved to the Council of Ministers, in accordance with paragraph 3 of the same legal standard, which is not technical but, political in nature.

Thirdly, it must be understood that there is no discretion, but binding, with regards to the conditions or formal requirements for a concentration to be subject to the control procedure [see Articles 36 to 39 of the PCL], since the model adopted depends on the private initiative, which is mandatory, and is likely to generate the practice of an offense provided for in Article 68(1)(f) of the PCL. Due to this factor, we consider that there is a sufficiently strong reason to conclude that the legislature did not intend to attribute discretion to the NCA in relation to these segments.

In fact, although the merger control procedure has a distinct nature comparing to the sanctioning process, an unsustainable antinomy is generated, in light of the criterion chosen for the definition of the discretionary segments, if we admit that the court is able to review, in totum, the decision of the NCA in these matters and no longer in the context of mergers. While it is true that most of these requirements include legal parameters and concepts, for which there would be other reasons to support their binding nature, it also covers elements closer to economic science, such as the delimitation of the relevant market, necessary for the calculation of the quota market, and also in the fair competition analysis, where European Union case-law has affirmed the existence of complex economic assessments. ${ }^{47}$

Therefore, revisiting the position that has been taken so far on the delimitation of the relevant market, we conclude that the segments referred to above should not be considered to be included at the discretion of the NCA. It should be noted that this understanding concerning the delimitation of relevant markets and, specifically, its effects on the type of judicial review is not innovative. In fact, Miguel Sousa Ferro maintains, although on different grounds, a normal judicial control. ${ }^{48}$

It is true that this results in a slight divergence from European Competition law, especially where these segments involve complex economic assessments. However, this is a consequence of the different nature that assumes the sanctioning dimension of Competition law, whose matrix is closer to criminal law and procedural criminal law and not to Administrative law, and is contrary to European Competition law.

For the same reasons and in general terms, that judgment applies to all cross sections between the sanctioning procedure and the merger control procedure, as is the case, for example, of the concept of dominant position presupposed by Article 41(4) of the PCL, which is common to the abuse of a dominant position (see Article 11 of the PCL). This, in particular, does not conflict with the case-law of the European Union, since, as Michael Harker, Sebastian Peyer and Katryn Wright point out, the

\footnotetext{
${ }^{47}$ See José Carlos Laguna da Paz, Understanding the limits..., 216 and note 102, indicating relevant caselaw, in particular Case T-342/99 Airtours, paragraph 26.

${ }^{48}$ Miguel Sousa Ferro, A definição dos mercados relevantes no direito europeu e português da concorrência: teoria e prática (Coimbra: Almedina, 2014), 613 and 670-672.
} 
Court in Airtours defined precisely the criteria for applying the concept of collective dominance, although it is based on principles of game theory that require a high level of expertise. ${ }^{49}$

Fourthly, with regard to decisions on merits (objection and non-opposition, or with commitments) and at the level of statute, the discretion of the Board is quite limited. Thus, according to the German doctrine and the position taken by Pedro Costa Gonçalves, it must be borne in mind that "when there is a probibition, a concentration must be probibited", ${ }^{50}$ because Article 53(1)(b) of the PCL does not allow that discretion.

In addition, and as a direct consequence of the principle of proportionality, it must be concluded that the NCA must accept the commitments submitted and issue a decision of non-opposition where they, together with conditions or obligations, are barriers to competition..$^{51}$ That view is in line with the position of the General Court expressed in the Ryanair case (Case T-342/07). ${ }^{52}$ This question is different, as Pedro Costa Gonçalves points out, from the "assessment of the Authority on the adequacy of the proposed commitments to eliminate competition problems". ${ }^{53}$

Thus, in the case of bounded segments, we consider that there is a general discretion regarding (i) the substantive decision-making criterion, which consists in creating significant impediments to effective competition in the national market or in a substantial part thereof [see Article 43(3) and (4) of the PCL] and (ii) the adequacy of the proposed commitments to eliminate barriers to competition.

In fact, in relation to these points and with the exception of the crossing segments mentioned above, there is no reason to conclude that the legislator did not intend to recognize the NCA's discretion, being certain that they involve technical and prognosis judgments and it is mainly in these points that the instrument of economic regulation must be recognized in the merger control procedure. ${ }^{54}$ Finally, it should be noted that in the application of the aforementioned substantive decision-making criterion, the NCA is not bound to the factors provided for in Article 41(2) of the PCL, since the list, as it appears from the legal expression used, is exemplary.

\section{Type of judicial control}

In relation to the binding segments, judicial control, in terms of intensity, can be classified as normal and full or merit.

What characterises this type of control at the level of the object of cognition is based on the fundamental idea that the Court's assessment will directly focus on the claim of the author and the confrontation of the claim with the applicable legal parameters, as in civil or criminal proceedings, where there is no first decision by a body other than the judiciary. That means that there is no link to the judgment expressed in the contested decision by the administrative agent.

\footnotetext{
${ }^{49}$ Michael Harker, Sebastian Peyer and Katryn Wright, Judicial scrutiny of merger..., 106.

${ }^{50}$ Pedro Costa Gonçalves, Controlo de Concentrações..., 293-294.

${ }^{51}$ See Pedro Costa Gonçalves, Controlo de Concentrações..., 295-296.

${ }^{52}$ Paragraph 28: "Where commitments have been validly proposed by the parties to the concentration during the administrative procedure in order to obtain a decision that the concentration is compatible with the common market, the Commission is required to examine the concentration as modified by those commitments. It is then for the Commission to demonstrate that those commitments do not render the concentration, as modified by the commitments, compatible with the common market (see, to that effect, in relation to the previous merger regulation, Case T 87/05 EDP v Commission [2005] ECR II 3745, paragraphs 63 to 65)".

${ }^{53}$ Pedro Costa Gonçalves, Controlo de Concentrações..., 296.

${ }^{54}$ Pedro Costa Gonçalves, Controlo de Concentrações..., 250-251.
} 
Consequently, the Court has full autonomy in the three relevant decisionmaking dimensions, namely: (i) the densification of normative concepts; (ii) in the determination of the relevant facts and in the assessment of evidence (considering the limits arising from the procedural principles related to the admissibility and/or assessment of evidence); (iii) and subsumption of the facts to the law. That is to say, the Court replaces the assessment made by the NCA by its own, or, when the analysis segment is not part of the subject-matter of the administrative decision (as for example in the case of incompetence) undertakes an unrestricted assessment.

This may lead to (i) a lack of competence, if the rules of jurisdiction laid down by law are infringed; (ii) a misuse of powers if the decision was not intended to defend and promote competition, but pursuit of distinct interests that objectively do not meet that end, whether private or public, or, in general; (iii) a violation of the law, whenever, due to an error of fact or an error of law, the decision of the NCA violates the legal parameters related to the other linked segments referred to.

At the decision-making level, the reform of administrative litigation that came into force on January 1, 2004 and in fulfillment of the right to effective judicial protection provided for in Article 268 (4) of the Constitution, according to the constitutional review of 1997, granted to the administrative courts unlimited jurisdiction, allowing, among other things, that the decision of the Court goes beyond the annulment or declaration of nullity of administrative acts and can order the Administration to practice the act due. The two applications may be cumulated in accordance with Article 4(2) (a) and (c) of the CPAC. This is not the case, for example, in European law, whose judicial control remains limited at the decision-making stage, since the Courts of the European Union, and specifically with regard to the decisions of the Commission, can only determine its annulment.

There is no reason to reject the possibility of cumulating requests in the actions under analysis, because of the reference made by Articles 91 and 92, paragraph 1, of the PCL, and because of the recent changes introduced to the CPAC, by Decree-Law $\mathrm{N}^{\mathrm{o}}$. 214-G/2015, of $02^{\text {nd }}$ Oct., there is only one form of proceeding, applicable to all non-urgent declaratory processes of administrative litigation.

Therefore, in cases where there is accumulation of claims and there is linked segments, the Court may not only annul or declare the decision of the NCA invalid but, can also order the Administration to practice the act due [see Article 71 (1) of the CPAC].

It should also be noted that, in respect of that decision-making level, recognition of a defect which may lead to the annulment of an act does not necessarily lead to a declaration of invalidity or annulment. Therefore, it is important to bear in mind, in the first case, the provisions of Article 162 (3) of the CPA, which excludes from the nullity regime the attribution of legal effects to situations of fact resulting from null acts, in accordance with the principles of good faith, the protection of trust and proportionality, or other constitutional legal principles, particularly associated with the passage of time. With regard to nullifying acts, Article 163, paragraph 5, of the $\mathrm{CPA}$, stipulates that the annulment effect does not take place when; the content of the annullable act cannot be different, since the act is of linked content or the assessment of the particular case allows only one solution to be identified as legally possible; the purpose for which the procedural or deferred formal requirement has been reached has been achieved by another means; there is no doubt that, even without the defect, the act would have been practiced with the same content. 
This is also the guideline of the European Union Courts. The Court in the Schneider case (T-310/01) stated the following assertions: "None the less, however incomplete a Commission decision finding a concentration incompatible with the common market may be, that cannot entail annulment of the decision if, and to the extent to which, all the other elements of the decision permit the Court to conclude that in any event implementation of the transaction will create or strengthen a dominant position as a result of which effective competition will be significantly impeded for the purposes of Article 2(3) of Regulation No 4064/89" (paragraph 412). ${ }^{55}$

Let us now look at the type of judicial control over the discretionary segments. At the level of the object of cognition, a distinction must be made between two distinct planes (i) a more peripheral plan, which focuses on the compatibility of these decision-making judgments with the substrate of juridicity, that underlies decision, i.e. with the limits of legality; (ii) a more nuclear one, which focuses on the judgment of merit, that is, on technical judgments and/or prognosis on the so-called complex economic assessments.

At the peripheral level, the Court may first verify whether the NCA has complied with the duty to state reasons, guaranteed by the Constitution itself, when the act affects legally protected rights or interests, as is the case [see Article 268(3) of the Constitution] and provided for in Articles 151(2) and 152(1) (a) of the CPA, ex vi Article 42, of the PCL. It is an appreciation from the point of view of its intelligibility, namely whether it is contextual (if it refers to that merger), whether it is clear (if it has no obscurity) and whether it is congruent (if it has no contradictions). ${ }^{56}$

Second, the Court can assess the compatibility of the NCA's decision with the basic legal principles governing the exercise of administrative activity, some of which have constitutional guarantees, such as the principles of equality, proportionality, fairness and impartiality, good faith [see Article 266 (2) of the Constitution] and others that are provided for in the CPA [see Articles 3 to 19 of the CPA]. In general terms, and following the proposal of Ana Raquel Gonçalves Moniz, it is possible to group these principles, with the exception of the principle of good faith expressed in the misuse of power, in three types of defects: (i) weighs up all the public interests present in the case ('concrete public interests"); (ii) "the decision differs from other decisions adopted in similar cases"; (iii) and "the decision is not adequate, necessary or proportional to the purpose envisaged by the legislator". ${ }^{57}$

The first type concerns breach of the principles of impartiality (in an objective dimension), rationality and reasonableness. Thus, from the principle of impartiality, it is incumbent upon the NCA to comply with the specific circumstances of the case in its decision. According to the other principles, it is the duty, in order for its decision to be rationally sustained and reasonable, to collect all the necessary elements to support it, to assess its credibility, to consider the various competing interests and the different possible perspectives.

The above assertions are in line with the parameters deriving from the case-law of the European Union on mergers, which are embodied in the formula introduced by the CJEU in the Tetra Laval case, in the sense that the Court can verify the material accuracy of the evidence that support the decision, its reliability and consistency, as well as its sufficiency, that is to say; whether these elements constitute all the relevant data which must be taken into account in order to assess a complex situation and whether they are capable of substantiating the

\footnotetext{
${ }^{55}$ See also decision in Chemical, paragraph 61.

${ }^{56}$ See Judgment of the Central Administrative Court of the North of $11^{\text {th }}$ Jan. 2013, 01772/07.7BEPR, STA ruling of May 27, 2009, case 0308/08; and Miguel Sousa Ferro, A Definição..., 593.

${ }^{57}$ Ana Raquel Gonçalves Moniz, A discricionariedade administrativa, 621-625.
} 
conclusions which they are removed..$^{58}$

The second type of defect referred to relates to breaches of the principles of Equality, legal certainty, and protection of confidence. According to these principles, the NCA cannot differ from other decisions adopted in similar cases. This is expressed in ordinary law in Article 152(1)(d) of the CPA, which includes the grounds of the decision. ${ }^{59}$ The practice of the NCA reveals the application of this command mainly in defining the relevant markets. It is clear that the principle of equality does not apply where previous decisions have been vitiated. In addition, and in view of the principle of impartiality, the NCA always has to analyze the particular features of the case, so that equality will go as far as the specific features of the merger agree to. In addition, respect for previous decisions is not absolute, as is clear from the aforementioned precept. However, the change of orientation has to be objectively justified.

The guidance adopted by the case law of the European Union Courts on this subject and in the specific context of the merger operations appears to be diverse. In the General Electric case (Case T-210/01), the CFI expressly stated, in light of the principle of the protection of legitimate expectations being supported by earlier caselaw, ${ }^{60}$ that "economic operators have no grounds for a legitimate expectation that a previous practice in taking decisions that is capable of being varied will be maintained" (paragraph 119), so that "[a] fortiori, they cannot plead such an expectation to challenge findings or assessments made in a given set of proceedings by invoking findings or assessments made in the context of just one previous case" (para. 119).

However, in the case of Sun Chemical Group (Case T-282/06), the CFI, although referring to these segments of the General Electric case, is not peremptory in its statement of principle, in the absence of any decisions taken in similar cases, since the reason which led it to dispel the parties' argument in this respect was that the credibility of alternative suppliers had to be assessed in accordance with the circumstances of each individual case and that, consequently, the assessment of the facts by the Commission in previous cases could not be transposed to the present case (para. 88). This is in line with the above assertions regarding the scope of the above principles. ${ }^{61}$

With regard to the Guidelines for the Economic Analysis of Horizontal Concentrations and the Guidance on the Adoption of Merger Commitments approved by the NCA, they can also generate a self-linking effect as a corollary of legal certainty and protection of trust, if that they are adjusted to the specificities of the concrete case and compatible with the applicable legal parameters.

With regard to the third type of defect, it includes breach of the principle of proportionality, in its well-known three dimensions, namely suitability, necessity and proportionality in the strict sense or just measure.

In concrete terms, and in order not to invade the NCA's own area of valuation, the application of that principle requires, in the context of prognosis judgments, and in accordance with the jurisprudence of the Court of Justice, in particular Tetra Laval

\footnotetext{
${ }^{58}$ See paragraph 39.

${ }^{59}$ See, in light of the most recent decisions, the decision given in concentration N. ${ }^{\circ} 27 / 2017$ Vallis Sustainable, paragraph 5, and in the concentration procedure Cent. 21/2017 - Luz Saúde/British Hospital, paragraph 14 and 20, in http://www.concorrencia.pt/FILES_TMP/2017_21_final_net.pdf.

${ }^{60}$ Judgments of the Court of First Instance in Case T-347/94 Mayr Melnhof v Commission [1998] ECR II 1751, N. ${ }^{\circ}$ 368, and of 30 September 2003 in Case T 203/01 Michelin v Commission [2003] II 4071, N. ${ }^{\circ}$ s 254 to 255 and 292 to 293.

${ }^{61}$ See for further developments on this issue, with an analysis of European jurisprudence, although in the context of the delimitation of relevant markets, Miguel Sousa Ferro, A Definição..., 593 et seq.
} 
(para. 43) and Sony, Case C-413/06 P (para. 47), "to envisage various chains of cause and effect with a view to ascertaining which of them is the most likely". Furthermore, it is also clear from that principle that commitments can be accepted only if the decision, without them, is to prohibit the concentration. In addition, it is also a corollary of the principle of proportionality that the NCA, in determining the conditions or obligations aimed at ensuring compliance with these commitments, guides its selection by vectors of adequacy, necessity and fair measure. ${ }^{62}$

Finally, and still in the peripheral dimension, the decision of the NCA cannot violate fundamental rights. ${ }^{63}$ This is not, of course, a question of the rights underlying the merger itself, in particular, the right to freedom of concentration, as this was weighed up by the legislature in determining the rules governing the control procedure. What is at stake is the non-infringement of other fundamental rights.

At the nuclear level of complex economic assessments of an economic nature or in prognosis judgments, an important distinction must be made between; "what are primary facts on the one hand, and what are assessments, or inferences constructed from the primary facts, on the other hand'. It is a difficult distinction. However, it is important that it be asked so that discretion is restricted to that nucleus which sustains it, in light of the material foundation above.

We propose a negative criterion. According to this criterion, it is considered a fact - in this sense of primary fact or "pure fact" - any fact that does not result in a judgment of prognosis, projection or probability.

Thus, in relation to such primary facts, the Court can control the so-called "error of fact", which, following the case law of the Administrative Courts on this matter "constitutes one of the grounds for invalidity of the administrative act, of a breach of a law which constitutes an illegality of a material nature 'and which consists in the divergence between the assumptions that the author of the act set out to protract the final administrative decision and its actual verification in the specific situation, resulting from the fact that considered in the administrative decision facts not proven or disconforming with reality, that is the grounds of the motivation of the act in question did not exist or had no dimension that was supposed by bim". ${ }^{64}$ It is clear that this defect may not lead to the annulment of the decision of the NCA if one of the cases provided for in Article 163 (5) of the CPA is found.

It should be noted that this position is in line with the European Union caselaw on the subject. In fact, although there are no general rules distinguishing between primary facts and complex economic assessments. The Court, in particular, in the case of Aalborg Portland (Case C-204/00 P), made it clear that the Court can verify the material accuracy of facts (paragraph 279). ${ }^{65}$

Lastly, as regards economic evaluations per se, that is to say, the hard core of the NCA's discretion, legal systems in general, however deferential, still admit a certain type of control, less intense. The differences are more terminological than content.

Thus, in the US and in relation to the interpretation of indeterminate or ambiguous concepts, Chevron step-two calls for reasonableness according to the criteria of interpretation, that is, even if the interpretation adopted is not that which the Court

\footnotetext{
${ }^{62}$ See Pedro Costa Gonçalves, Controlo..., 286-287.

${ }^{63}$ It should be borne in mind that in respect of certain matters such as freedom of expression, the protection of potentially affected fundamental rights is ensured through binding decisions by the respective entities.

${ }^{64}$ Supreme Administrative Court ruling of $12^{\text {th }}$ March 2009, case n. ${ }^{\circ}$ 0545/08.

${ }^{65}$ See also the extensive conclusions of Advocate General Tizzano in the Tetra Laval case: discretion inherent in that type of assessment and cannot replace the body to which those paragraph 85 and 86 .
} 
would undertake, it must accept it when it is reasonable or permissible in the light of those criteria, in which case there is judicial deference. Therefore, if the interpretation is unreasonable, there will no longer be judicial deference. In the case of "agency's policy judgment", the so-called "arbitrary and capricious test" applies. ${ }^{66}$

In the United Kingdom, the concept of "irrationality", known as "Wednesbury unreasonableness", is used when no reasonable decision-maker would have reached the decision subject to judicial review on the basis of the facts, evidence and any relevant assertions it has. ${ }^{67}$

In France, the concept of manifest error of assessment was adopted, ${ }^{68}$ which is a gross error which no reasonable person would have committed. This is also the concept used by European Union case-law and our administrative case-law and doctrine. ${ }^{69}$

There is no reason why this criterion should not also be applied in the field of mergers. It is a specificity, justified by the specialisation of judicial review in the matter. Thus, gross error should not only be based on common sense, but also on the basis of parameters which, perhaps having their origin in the economy, have been assimilated by competition law if there is a general consensus on their sense. And in this context the jurisprudence of the European Union Courts can be an important aid tool. Along the same lines, it should also include, in the Schneider case, choices of econometric instruments and approaches that are manifestly contrary to accepted rules of economic discipline (para. 132).

Lastly, at the decision-making level, the Court is also not limited, in respect of those segments, to annul the decision of the Board. It can issue decisions of condemnation, having accumulation of requests to that direction. However, except in cases designated as "zero discretion", 70 that is to say, where "from the particular circumstances of the case it follows that only a solution proves to be legally viable", that decision of conviction shall not result in the definition of the content or meaning of the decision of the NCA, but in the delimitation of the elements and/or vices that the NCA must investigate and/or delete. It will be a "framework sentence". ${ }^{71}$

\section{Conclusions}

Based on the above assumptions, is possible to synthesize them in the following essential vectors:

a) European Competition law is not directly applicable to the judicial control of NCA's decisions in mergers control procedure, because it is, firstly, a domestic problem, without prejudice to recourse to European Union case-law as a criterion for interpretation;

b) Under domestic law, the solution must be found in Articles 3(1), 71(2) and 91(5) of the CPAC, which are applied through Articles 91 and 92(1), both of the PCL;

c) The application of these rules requires a distinction to be made between the binding segments and the discretionary segments;

\footnotetext{
${ }^{66}$ Jan S. Oster, The Scope..., 1284-1285.

${ }^{67}$ See Matthew O'Regan and Ruth Jefferson, "Merger litigation in the United Kingdom", The Antitrust Bulletin, vol. 58, n. ${ }^{\circ} \mathrm{s} 2$ and 3 (2013): 469.

${ }^{68}$ See Nicolas Petit and Rabeux Louise, Judicial..., 110.

${ }^{69}$ See Vieira de Andrade, Os poderes..., 38.

${ }^{70}$ Ana Raquel Gonçalves Moniz, A discricionariedade..., 618.

${ }^{71}$ For further developments about the concept António Cadilha, Os Poderes..., 195 et seq.
} 
d) The criterion adopted does not distinguish between volitional discretionary and cognitive discretion and seeks to determine the will of the legislator, by means of interpretation and in the name of the Principle of Separation and interdependence of powers, circumscribing the possibility of recognition of discretion, according to the material foundations that also support it, to technical judgments, judgments of prognosis, judgments of rationalisation of resources or strategic decisions;

e) The application of this criterion to the NCA's formal decision does not subject the merger to the control procedure. The merits decisions lead to the recognition of discretion only in relation to the following segments: (i) the substantive decision-making criterion, consisting of creating significant barriers to effective competition in the national market or a substantial part of it [see Article 43 (3) and (4) of the PCL] and (ii) adequacy of proposed commitments to remove barriers to competition;

f) In any case, the cross-sections with the sanctioning dimension of the PCL are always bound, and this is one of the few points of divergence between domestic law and European competition policy in this area;

g) The type of judicial control in relation to the related parties is a normal, full or meritorious control which implies full independence of the Court: (i) in the densification of the normative concepts; (ii) in the determination of the relevant facts and in the assessment of evidence; (iii) and in subsumption of the facts to the law;

h) The type of judicial control in respect of discretionary segments is limited, marginal, or legal control, which takes place on two levels; (i) one more peripheral, which focuses on the compatibility of these decisive judgments with the substrate of juridicity that underlies the decision, that is, with the limits of juridicity and (ii) a more nuclear one, which focuses on the merits judgment, that is, on the technical and/or prognosis judgments or on the said complex economic assessments and that allow the control of the error of fact and the manifest error of assessment. 